\title{
COMUNICAÇÃO
}

\section{OBSERVATIONS ON POTENTIAL TICK VECTORS OF HUMAN DISEASE IN THE CERRADO REGION OF CENTRAL BRAZIL}

\section{J. C. Knight}

The chaging ecology of the Cerrado region through extensive agricultural and human development ${ }^{3}$ has meant increasing opportunities for human contact with natural foci of zoonotic tick-borne disease and enhancement of rodent hosts. The existence of Lyme disease has been postulated in Brazil6; infection due to Richettsia richettsii is well documented ${ }^{2}$. The details of a small study made between March and May 1991 are reported here, and aspects of potential vector epidemiology. The results of arbovirus isolation from ticks brought back to the U.K. will be reported elsewhere.

Collection sites included District Federal (16'S $48^{\prime} \mathrm{W}$ ); Mambai, Goias (14'30"S 46'W); and Uberaba, Minas Gerais (19'S 48'W). Tick abundance in the Cerrado region is highly seasonal ${ }^{5}$ from May to a maximum in July coinciding with the hot dry period.

A limited number of Ixodidae species were found living in close proximity to man, with 4 genera, Amblyomma, Anocentor, Rhipicephalus and Boophilus represented in the collection (Table1). Anocentor, represented by the single species Anocentor nitens (Neumann) was the most abundant and made up $66 \%$ of the 1357 ticks collected. Amblyomma, with two species Amblyomma cajennense (Fabricius) and Amblyomma rotundatum (Koch), made up 6\%; the other genera represented by 1 species each, Rhipicephalus sanguineus (Latereille) and Boophilus microplus (Canetsrini) made up $9 \%$ and $19 \%$ respectively (Table 1 ).

A total of 273 animals were examined for ticks. A very high degree of hosts pecificity was found. Of

Table I - Ixodid ticks collected.

\begin{tabular}{lccccccc}
\hline Genus & $\begin{array}{c}\mathrm{N}^{\mathrm{o}} \text { of } \\
\text { species }\end{array}$ & $\begin{array}{c}\text { Adult } \\
\text { females }\end{array}$ & $\begin{array}{c}\text { Adult } \\
\text { males }\end{array}$ & Nymphs & Larvae & Total & $\begin{array}{c}\% \text { of } \\
\text { total }\end{array}$ \\
\hline Amblyomma & 2 & 34 & 7 & 35 & - & 76 & 6 \\
Anocentor & 1 & 408 & 284 & 199 & 6 & 897 & 66 \\
Rhipicephalus & 1 & 53 & 64 & 5 & - & 122 & 9 \\
Boophilus & 1 & 211 & 41 & 8 & 2 & 262 & 19 \\
\hline Total & 5 & 706 & 396 & 247 & 8 & 1357 & \\
\hline
\end{tabular}

and this was confirmed with a questionnaire $(n=48)$ in which local people reported tick numbers rising

\footnotetext{
Vising research student, Núcleo de Medicina Tropical, Universidade de Brasilia, Brasília, DF, Brasil.

Recebido para publicação em 26/11/91.
}

77 dogs examined, 16 (20\%) were found to be infested withRhipicepahlus sanguineus; of 37 horses $34(92 \%)$ had Anocentor nitens and 9(24\%) also had Amblyomma cajennense: of 67 cows (mixed Zebu breed $50(75 \%)$ had a Boophilus microplus load; and 
Comunicação. Knight JC. Observations on potencial tick vectors of human disease in the Cerrado region of central Brazil. Revista da Sociedade Brasileira de Medicina Tropical 25:145-146, abr-jun, 1992.

of 27 goats examined Anocentor nitens was present in $8(30 \%)$. Wild animals examined included armadillo, deer, fox, frog, tapir, emu and boa constrictor; only the latter were found to have ticks present with heavy infestation of Amblyomma rotundatum. No small mammals were caught from a total of 60 trap nights during the study in Mambai. Careful search and partial demolition of 19 chicken houses revealed no Argasidae. Very few free-living or questing ticks were encoutered at the time of the study despite extensive flagging and burrow sampling using a portable vacuum suction device.

The absence of Ixodes from the collection is notable given its vector status in Lyme disease, but the presence in Brazil of at least ${ }^{9}$ species is recorded ${ }^{1}$, and small mammal surveys ${ }^{4}$ reveal ectoparasites including Ixodes and Amblyomma species on Dephinae and Muridae

The risk of tick bites is seasonal and related to outdoor activities, with farm workers and children at most apparent risk. Low biting rates were obtained during the relatively inactive period during which the study took place, with a positive history ( 3 month recall) in only $6 \%$ of those questionned $(\mathrm{n}=48)$. Clinical manifestations following tick bites included only local rashes and fever.

In conclusion, there appears to be a limited seasonal risk of tick bites to the humam population. The Cerrado region is rapidly changing with agricultural development and humam migration, such that little primary cerrado remains. Increased tick-man contact in areas of potential zoonotic foci exists, but this study revealed that a limited number of tick species appear to occur in close proximity to man, and these did not include examples of the genus lxodes.

\section{ACKNOWLEDGMENTS}

I would like to thank Dra. Vanize Macedo and Prof. Philip Marsden at the Nucleo de Medicina Tropical. Specimens were confirmed at the Cidade Universidade, Sao Paulo and the Natural History Museum, London.

\section{REFERENCE}

1. Argao H, Fonseca FA. Notas de Ixodologia. VIII Lista e chave para os representantes da fauna Ixodológica Brasilieira. Memorias do Instituto Oswaldo Cruz 59: 115-130, 1961.

2. Dias E, Vianna-Martins A. Spotted fever in Brazil. A Summary. The American Journal of Tropical Medicine and Hygiene 19: 103-108, 1939.

3. Furley PA, Ratter JA. Soil resources and plant communities of the central Brasilian cerrado and their development. Journal of Biogeography 15 : 97 108, 1988.

4 Mares MA, Braun JK, Gettinger D. Observations on the distribution and ecology of the mammals of the cerrado grasslands of central Brazil. Annals of Carnegie Museum 58: 1-60, 1989.

5 Ministerio da Agricultura, Secretaria Nacional de Defensa Agropecuária, Secretaria de Defensa Sanitaria Animal. Carrapato, Berne e Bicheira no Brasil 1983. Impresso no: Pan-Americano de febre aftosa. Organização Pan-Americana de Saúde Organização Mundial de Saúde, 1985.

6 Yoshinari NH, Steere AC, Cossermelli W. Revisāo da Borreliose de Lyme. Revista da Associação Médica Brasileira 35: 34-38, 1989. 